\begin{tabular}{ll|l} 
Case Reports in & \multicolumn{2}{c}{ Case Rep Gastroenterol 2016;10:206-211 } \\
\cline { 2 - 3 } Gastroenterology & $\begin{array}{l}\text { Published online: May 20, } 2016 \\
\text { Published by S. Karger AG, Basel } \\
\text { www.karger.com/crg }\end{array}$ \\
\cline { 2 - 3 } & $\begin{array}{l}\text { This article is licensed under the Creative Commons Attribution-NonCommercial } 4.0 \\
\text { International License (CC BY-NC) (http://www.karger.com/Services/OpenAccessLicense). } \\
\text { Usage and distribution for commercial purposes requires written permission. }\end{array}$
\end{tabular}

\title{
Pulmonary Crohn's Disease in Down Syndrome: A Link or Linkage Problem
}

\author{
Danyal Thaver Mirza Beg \\ Department of Pediatrics, SUNY Upstate Medical University, Syracuse, N.Y., USA
}

\section{Keywords}

Crohn's disease - Down syndrome · Pediatric population · Pulmonary Crohn's disease · Lung nodules

\begin{abstract}
Crohn's disease (CD) is an autoimmune inflammatory disorder that primarily affects the gastrointestinal tract. It may have pulmonary involvement, which has been rarely reported in pediatric patients. Down syndrome (DS) has been associated with increased frequency of autoimmune diseases. However, associations between CD and DS have been rarely reported. We present the case of a 5-year-old girl with known DS and a history of chronic intermittent abdominal pain who presented with persistent pneumonia. Her workup included a chest computed tomography (CT) scan that showed multiple noncalcified pulmonary nodules. An extensive infectious workup was done that was negative. CT-guided needle biopsy of the lung nodules showed necrotizing granulomas. This raised concern for primary CD with extraintestinal pulmonary manifestation. An esophagogastroduodenoscopy and colonoscopy were performed, and colon biopsies showed scattered epithelioid granulomas. Based on this information, there was consensus that her lung nodules were secondary to $C D$. She was started on standard therapy for $C D$, and her abdominal and respiratory symptoms gradually improved. However, she continues to have mild residual lung calcification and fibrosis. To our knowledge, this is the first reported case of pulmonary CD in a child with DS. The natural history of pulmonary $C D$ in the pediatric population is not very well studied. Furthermore, since DS has been well known to be associated with increased frequency of malignancies and
\end{abstract}

\section{KARGER}




\section{Case Reports in Gastroenterology}

Case Rep Gastroenterol 2016;10:206-211

(c) 2016 The Author(s). Published by S. Karger AG, Basel www.karger.com/crg

Thaver and Beg: Pulmonary Crohn's Disease in Down Syndrome: A Link or Linkage Problem

autoimmune conditions due to immune dysregulation, it is difficult to predict the severity and possible complications in this patient.

(C) 2016 The Author(s)

Published by S. Karger AG, Basel

\section{Introduction}

Crohn's disease (CD) is an autoimmune inflammatory disorder that may involve different sites along the gastrointestinal tract. It may have several different manifestations including symptoms due to extraintestinal metastasis. The disease tends to be more severe and widespread in children and young adults [1,2]. During the last 2 decades, the incidence of CD in childhood has considerably increased $[2,3]$.

Pulmonary involvement in CD is well described, and though it is rarely reported in pediatric patients, it may be more common than previously reported [4]. Pulmonary CD can be latent or symptomatic, with symptoms manifesting before, during or after the diagnosis of CD.

Down syndrome (DS) has been associated with increased frequency of malignancies, autoimmune diseases and infections. It has been hypothesized that this is due to abnormal precocious aging [5]. However, recent evidence suggests that it is more likely that the immune system in DS is deficient from the very beginning, with immune dysregulation causing a tendency towards autoimmune diseases [6]. In addition to other congenital defects [7], individuals with DS are also more likely to have structural and functional disorders of the gastrointestinal tract [8]. Associations between CD and DS have been reported, though very rarely [9-13]. In our search of the literature, we did not find any reported case of DS with pulmonary $\mathrm{CD}$ to date.

\section{Case Report}

A 5-year-old girl with known DS and a history of chronic intermittent abdominal pain presented to the emergency department with worsening symptoms. Her abdominal pain has previously been attributed to underlying chronic constipation and possible irritable bowel syndrome. Workup for her abdominal pain included serologic testing for celiac disease, which showed increased anti-gliadin IgA and IgG but normal tissue transglutaminase IgA. On presentation to the emergency department, an abdominal X-ray was done due to suspicion of constipation, and a chest X-ray confirmed left lower lobe pneumonia. She was treated for presumed pneumonia with oral antibiotics. She then returned to the hospital due to persistent fevers and abdominal pain and was admitted for 5 days for intravenous antibiotics. On serial chest X-rays during the hospitalization and after discharge, she seemed to have persistent left-sided and perhilar infiltrates that remained essentially unchanged in appearance. A pediatric pulmonologist was consulted, who felt that she had no symptoms suggestive of asthma, aspirated foreign body, cystic fibrosis, primary ciliary dyskinesia or immunodeficiency.

A chest computed tomography (CT) scan was done that showed multiple noncalcified pulmonary nodules bilaterally, mainly peripheral in location. The largest nodule measured $8.0 \mathrm{~mm}$ and was in the posterior medial aspect of the superior segment of the left lower lobe adjacent to the pleura. The second largest was $7.0 \mathrm{~mm}$ in the right pulmonary apex, and another 2 nodules measuring $4.0 \mathrm{~mm}$ were seen in the right upper lobe (fig. 1). Two additional 4.0-mm nodular densities were seen in the posterior periphery of the superior segment of 
the left lower lobe just caudal to the dominant lesion. There were localized patchy reticular nodular infiltrates in an extreme superior aspect of the superior segment of the left lower lobe and similar extensive infiltrates extending from the suprahilar region on the right side into the right pulmonary apex. These infiltrates demonstrated patchy confluence and air bronchograms with nodularity as well. There was evidence of significant pleural effusion.

Based on these findings, the patient was referred to the Department of Pediatric Infectious Diseases for further workup. Lymphocyte subsets, immunoglobulin levels and vaccine responses to tetanus and pneumococcus were done, as well as a neutrophil oxidative burst assay for chronic granulomatous disease. Neutrophil function showed $74 \%$ activity at $48 \mathrm{~h}$, which was considered a normal response and not compatible with a diagnosis of chronic granulomatous disease. Her immunoglobulin assay showed an IgG level of 1,130 mg/dl (range 226-1,870), an IgA level of $218 \mathrm{mg} / \mathrm{dl}$ (range 3-155) and an IgM level of $45 \mathrm{mg} / \mathrm{dl}$ (range 12-219). She showed a normal response to the 23-valent pure polysaccharide pneumococcal vaccine. Her tetanus antibody level was $0.97 \mathrm{IU} / \mathrm{ml}$, which was considered a normal immunization response. She had negative blastomyces and histoplasma antibody levels.

Her lymphocyte subsets were all within normal range. Results showed a CD19 B-cell count of 127 cells $/ \mu \mathrm{l}$, a CD3 T-cell count of 1,033 cells/ $\mu \mathrm{l}$, a CD4 cell count of 605 cells/ $\mu \mathrm{l}$, a CD8 cell count of 395 cells/ $\mu \mathrm{l}$, and a CD56/16 natural killer cell count of 99 cells/ $\mu \mathrm{l}$; the CD4/CD8 ratio was normal at 1.5. After a relatively extensive infectious workup, she underwent a bronchoscopy and CT-guided needle biopsy of the lung nodules. Bronchoscopy showed normal mucosa. The branching pattern also was normal; however, the right upper lobe bronchus gave only 2 branches compared with the usual 3 branches. There were normal secretions. Broncheoalveolar lavage (BAL) analysis was performed, and specimens were sent for bacterial, fungal and mycobacterial culture analysis as well as for cytology. No acidfast bacilli were seen on fluorochrome stain, and culture results showed no organisms even after 56 days of incubation. Cytology results showed scant bronchial cells and scattered macrophages. The Oil Red O (lipid) stain was negative. CT-guided core lung biopsies showed extensive necrosis with surrounding palisading histiocytes, fibrosis and chronic inflammation (fig. 2). Acid-fast bacillus and Grocott's methenamine silver stains were negative for any organisms.

\section{Diagnosis}

These findings, along with the history of chronic abdominal pain, raised concern for primary CD with secondary involvement of the lungs. An esophagogastroduodenoscopy and colonoscopy were performed. The esophagogastroduodenoscopy showed localized mild mucosal abnormality characterized by congestion, erosion and inflammation in the 3rd part of the duodenum. A benign-appearing, intrinsic moderate stenosis was found at the pylorus. This was traversed using a neonatal scope with some difficulty. Diffuse, severe mucosal abnormality characterized by congestion, discoloration, erythema, erosion, friability, granularity, inflammation and nodularity was found in the entire examined stomach. On colonoscopy, patchy, mild inflammation characterized by congestion (edema), erythema and aphthous ulceration was found in the cecum, ascending colon, transverse colon and descending colon. Normal mucosa was seen in the rectum.

The gastric biopsy exhibited moderate to focally marked expansion of the lamina propria by a mixed leukocytic population. Also present were scattered areas of neutrophils, some of which were present in the surface epithelium. A Giemsa stain was performed and 
demonstrated the presence of bacteria (these bacteria, however, did not have the usual morphological features of Helicobacter). A periodic acid Schiff stain was performed and demonstrated no fungi. Both the cecum and ascending colon biopsies exhibited cryptitis as well as eosinophilia of the lamina propria. Also present were focal aggregates of histiocytes (although well-formed epithelioid granulomas were not observed). In contrast, the transverse colon and descending colon biopsies showed similar cryptitis and eosinophilia and, in addition, there were scattered epithelioid granulomas. No necrosis was observed related to these granulomas. Acid-fast bacillus and Grocott's methenamine silver stains were performed on these specimens, and no organisms were seen. These findings were suggestive of $\mathrm{CD}$. Based on this information, there was consensus that her lung nodules were secondary to CD. She was then started on mesalamine and later on infliximab and methotrexate. With the start of therapy, her abdominal symptoms gradually resolved. However, she continues to have some residual lung calcification and mild fibrosis.

\section{Conclusion}

To our knowledge, this is the first reported case of pulmonary CD in a child with DS. The natural history of pulmonary CD in the pediatric population is not very well studied. Furthermore, since DS has been well known to be associated with increased frequency of malignancies and autoimmune conditions due to immune dysregulation, it is difficult to predict the severity and possible complications in this patient.

\section{Acknowledgement}

The authors would like to acknowledge Ms. Samantha Vemula, fourth-year medical student at SUNY Upstate Medical University, for her help with referencing.

\section{Statement of Ethics}

The authors have no ethical conflicts to disclose.

\section{Disclosure Statement}

The authors have no conflicts of interest.

\section{References}

1 Freeman HJ: Natural history and long-term clinical course of Crohn's disease. World J Gastroenterol 2014;20:31-36.

2 Ruel J, Ruane D, Mehandru S, Gower-Rousseau C, Colombel JF: IBD across the age spectrum: is it the same disease? Nat Rev Gastroenterol Hepatol 2014;11:88-98.

-3 Malmborg P, Hildebrand H: The emerging global epidemic of paediatric inflammatory bowel disease causes and consequences. J Intern Med 2016;279:241-258.

4 Vadlamudi NB, Navaneethan U, Thame KA, Kelly DR, Dimmitt RA, Harris WT: Crohn's disease with pulmonary manifestations in children: 2 case reports and review of the literature. J Crohns Colitis 2013;7:e85-e92. 


\section{Case Reports in \\ Gastroenterology}

\begin{tabular}{l|l}
\hline Case Rep Gastroenterol 2016;10:206-211 \\
\hline & $\begin{array}{l}\text { C } 2016 \text { The Author(s). Published by S. Karger AG, Basel } \\
\text { www.karger.com/crg }\end{array}$ \\
\hline
\end{tabular}

Thaver and Beg: Pulmonary Crohn's Disease in Down Syndrome: A Link or Linkage Problem

5 Cuadrado E, Barrena MJ: Immune dysfunction in Down's syndrome: primary immune deficiency or early senescence of the immune system? Clin Immunol Immunopathol 1996;78:209-214.

-6 Kusters MA, Verstegen RH, Gemen EF, de Vries E: Intrinsic defect of the immune system in children with Down syndrome: a review. Clin Exp Immunol 2009;156:189-193.

7 Cleves MA, Hobbs CA, Cleves PA, Tilford JM, Bird TM, Robbins JM: Congenital defects among liveborn infants with Down syndrome. Birth Defects Res A Clin Mol Teratol 2007;79:657-663.

8 Moore SW: Down syndrome and the enteric nervous system. Pediatr Surg Int 2008;24:873-883.

9 Yamamoto M, Abo W, Hori T, Nakada T, Tachibana N, Hatada Y, et al: Crohn's disease in a child with Down syndrome. Pediatr Int 2002;44:537-539.

10 Souto-Rodriguez R, Barreiro-de-Acosta M, Dominguez-Munoz JE: Down's syndrome and inflammatory bowel disease: is there a real link? Rev Esp Enferm Dig 2014;106:220-222.

11 Vajro P, Cucchiara S, Vegnente A, Iorio R, de Silva C, Cipolletta L, et al: Primary sclerosing cholangitis preceding Crohn's disease in a child with Down's syndrome. Dig Dis Sci 1998;43:166-169.

12 Persic M, Dessardo S, Subat-Dezulovic M, Ahel V, Rozmanic V: Down syndrome and Crohn's disease: an extremely rare association. Pediatr Int 2001;43:519-521.

13 Burgess JN, Kelly KA: Regional enteritis and Down's syndrome. Minn Med 1971;54:793-794.

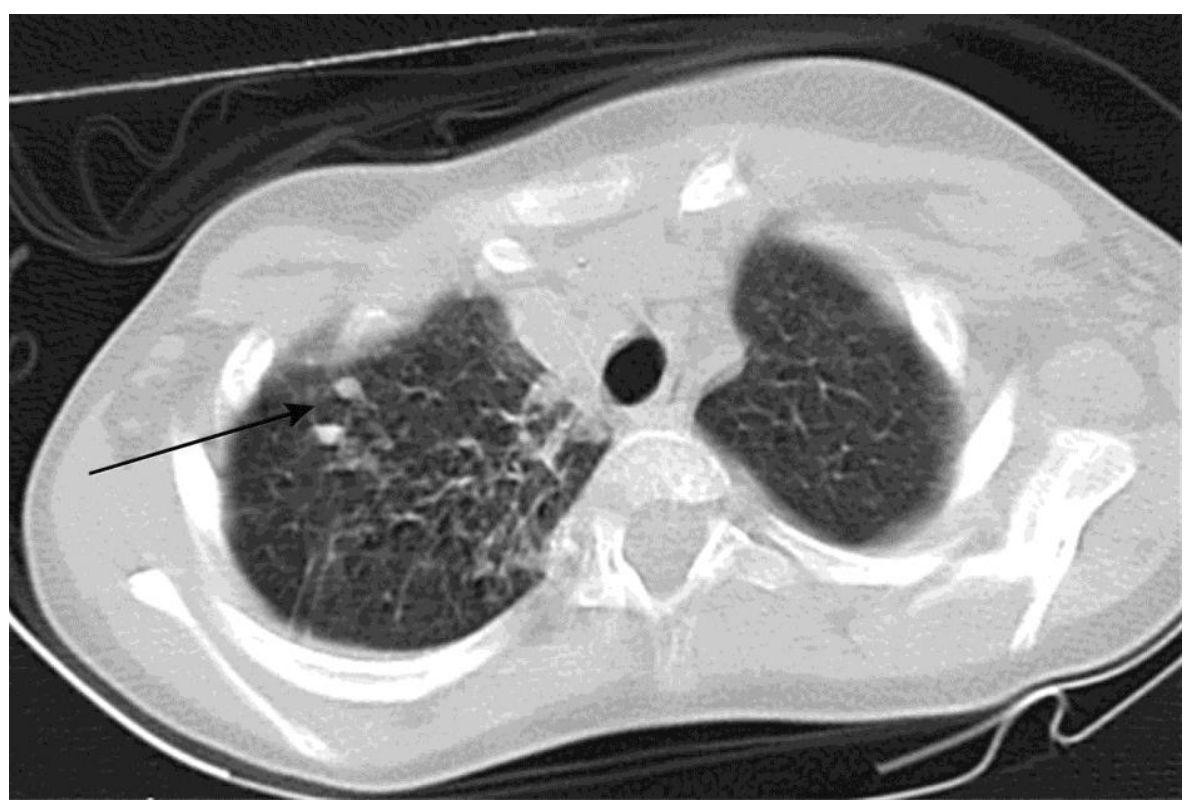

Fig. 1. CT scan of the lung showing pulmonary nodules in the right upper lung (arrow). 


\begin{tabular}{|c|c|}
\hline \multirow{2}{*}{$\begin{array}{l}\text { Case Reports in } \\
\text { roenterology }\end{array}$} & Case Rep Gastroenterol 2016;10:206-211 \\
\hline & \begin{tabular}{l|l} 
& $\begin{array}{l}\text { @ } 2016 \text { The Author(s). Published by S. Karger AG, Basel } \\
\text { www.karger.com/crg }\end{array}$
\end{tabular} \\
\hline
\end{tabular}

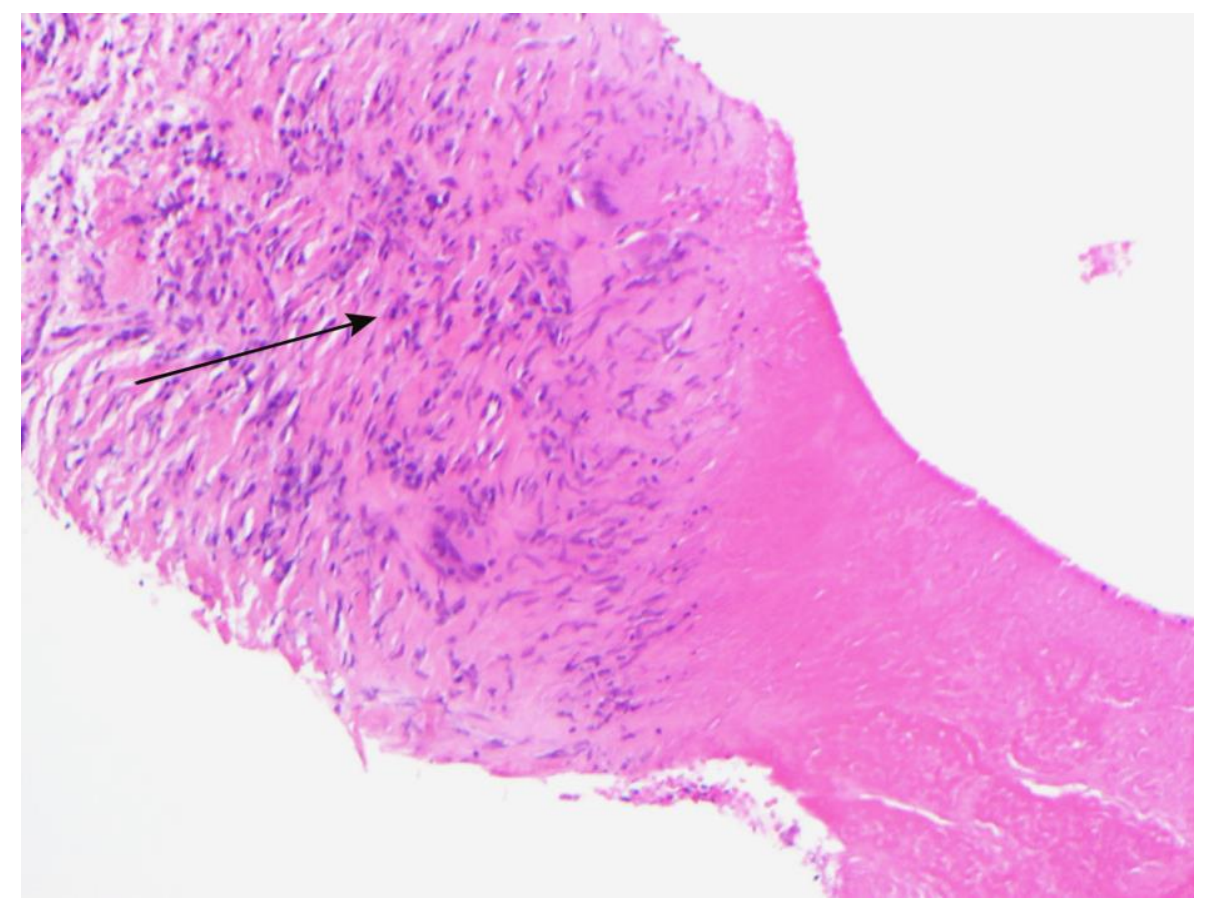

Fig. 2. High-power image $(\mathrm{H} \& \mathrm{E}, \times 40)$ showing histiocytes (arrow) next to the area of necrosis. 